\title{
Genetic diversity of long-established populations of Elaeis guineensis Jacquin (Arecaceae)
}

\author{
Kyvia Pontes Teixeira das Chagas ${ }^{1}$, Ageu da Silva Monteiro Freire ${ }^{2}$, Luciana Gomes Pinheiro ${ }^{3}$, \\ Cristiane Gouvêa Fajardo ${ }^{4}$, Fábio de Almeida Vieira ${ }^{5}$
}

\begin{abstract}
This study aimed to estimate the genetic diversity of three Elaeis guineensis populations in Rio Grande do Norte state, as well as to verify the decreases in effective population size. The population with the highest polymorphism was MAT (Mata) with +57 loci (72\%), followed by RIA (Riacho) with 54 loci (68\%) and HOR (Horta) with 34 loci (43.03\%). The RIA population was shown to be the most genetically diverse, with Nei $(h=0.28)$ and Shannon $(I=0.41)$ diversity indices. There was high genetic differentiation among populations (AMOVA, analysis of molecular variance $=42 \%$ ), which was separated into three distinct genetic groups according to a Bayesian analysis. There was a significant population decrease $(P<0.05)$ for the HOR population in the IAM (infinite allele model) and SMM (stepwise mutation model), and for the RIA population in the IAM. The data obtained in this study may support ex-situ conservation projects for Elaeis guineensis, contributing to the selection of genotypes and their sustainable use.
\end{abstract}

Index terms: Molecular Marker, Bottleneck, ISSR, Conservation.

\section{Diversidade genética em populações longas estabelecidas de Elaeis guineensis Jacquin (Arecaceae)}

Corresponding author: kyviapontes@gmail.com

Received: February 12, 2019 Accepted: April 29, 2019

Copyright: All the contents of this journal, except where otherwise noted, is licensed under a Creative Commons Attribution License.
Resumo-Este trabalho objetivou estimar a diversidade genética de três populações de Elaeis guineensis no Estado do Rio Grande do Norte, bem como verificar a diminuição do tamanho efetivo da população. A população com maior polimorfismo foi a MAT (Mata) com 57 locos (72\%), seguida pela RIA (Riacho), com 54 locos (68\%), e HOR (Horta), com 34 locos (43,03\%). A população RIA mostrou-se a mais diversificada geneticamente, com índices de diversidade de Nei $(h=0,28)$ e índice de Shannon $(I=0,41)$. Houve alta diferenciação genética entre as populações (AMOVA, análise de variância molecular $=42 \%$ ), que foi separada em três grupos genéticos distintos, de acordo com uma análise bayesiana. Houve uma diminuição significativa da população $(P<0,05)$ para a população HOR no modelo IAM (modelo de alelos infinitos) e SMM (modelo de passos de mutação), e para a população RIA no IAM. Os dados obtidos neste estudo podem apoiar projetos de conservação exsitu para Elaeis guineensis, contribuindo para a seleção de genótipos e seu uso sustentável.

Termos para indexação: Marcadores Moleculares, Gargalo Genético, ISSR, Conservação.

${ }^{1} \mathrm{MSc}$ in Forestry Sciences, Federal University of Rio Grande do Norte, Macaíba, Rio Grande do Norte, Brazil. E-mail: kyviapontes@gmail.

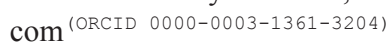

${ }^{2}$ Forest Engineer, Federal University of Rio Grande do Norte, Macaíba, Rio Grande do Norte, Brazil. E-mail: ageufreire@hotmail.com ${ }^{\text {(ORCID }}$ 0000-0002-5364-0859)

${ }^{3}$ MSc in Forestry Sciences, Federal University of Rio Grande do Norte, Macaíba, Rio Grande do Norte, Brazil. E-mail: luciana.gpinheiro@ yahoo.com.br (ORCID 0000-0002-9115-4210)

${ }^{4}$ DSc of Ecology, Federal University of Rio Grande do Norte, Macaíba, Rio Grande do Norte, Brazil. E-mail:genegoista00@gmail.com ${ }^{\text {(ORCID }}$ 0000-0001-6202-71431

${ }^{5}$ DSc of Forestry Engineering, Federal University of Rio Grande do Norte, Macaíba, Rio Grande do Norte, Brazil. E-mail: vieirafa@gmail.com ${ }^{\text {(ORCID }}$ 0000-0003-3347-255X) 


\section{Introduction}

Plants in the Arecaceae family are amongst the most economically important species in Brazilian forests. In addition to having a direct relationship with the agricultural sector, these species have several non-timber forest products of economic and ecological importance such as leaves, fruits, seeds and oils (MARTINS et al., 2012). The Elaeis guineensis palm tree is popularly known as oil palm. Its economic prominence is due to its oil, being one of the world's leading sources of vegetable oil. (FERREIRA et al., 2012; USDA, 2012). E. guineensis oil can be extracted from both the fruit (palm oil) and the nut (palm kernel oil). It has several uses in the pharmaceutical and food industry, as well as for producing biofuels (ABREU; OLIVEIRA; GUERRA, 2010). As it comes from a renewable energy source, palm oil can be used as biodiesel (KUSS et al., 2015).

Planting E. guineensis on different soils and its use for various activities means that it is increasingly important to consider ex-situ conservation of this species (CHAGAS et al., 2015). Research with palm trees has been significantly growing over the years, demonstrating the importance of understanding the genetic and ecological aspects of the species (CHAGAS et al., 2015; FAURBY et al., 2016).

Through genetic studies of forest populations, knowledge about the genetic variability and the distribution of genotypes in space have been useful for both genetic conservation and genetic improvement (BRANDÃO et al., 2011). Genetic diversity can be estimated by molecular markers, currently focused on ISSR markers (Inter-Sequence Simple Repeats). ISSRs are useful in detecting polymorphism because they have low cost, are abundant in the genome and easily repeatable between laboratories, therefore being frequently used in population genetics studies (ADHIKARI et al., 2017). Among the factors that can influence population genetic diversity are recent anthropic action, the population size, the population isolation, gene flow, reproductive system and environmental events (VIEGAS et al., 2011).

This study was aimed at analysing the genetic diversity in Elaeis guineensis populations through ISSR molecular markers. It also aims to detect the occurrence of possible population genetic bottlenecks.

\section{Material and methods}

\section{Study site}

The study was carried out in three E. guineensis populations located in the city of Macaíba, Rio Grande do Norte (Table 1). The vegetation has transition zones and areas of Caatinga, and some fragments of Atlantic forest are found.
An anthropogenic pressure scale was constructed using the presence and intensity of the following items: agricultural activity, ruminant and/or domestic animals, selective cutting and erosion. Each of these factors was assigned a score between 0 to 10 . Using the formula: $\left(\sum_{n}\right.$ $\mathrm{x}$ QN) $\div \mathrm{VM}$, where $\sum$ is the sum of all of the scores, $\mathrm{QN}$ is the number of levels, and VM is the maximum possible value in the total record of the factors, level one was deemed to be the most preserved and the level five the most degraded (SANTOS; VIEIRA, 2005).

\section{Sampling}

We sampled vegetal material of 43 E. guineensis individuals. The plant tissue was stored in $2 \mathrm{~mL}$ plastic tubes containing $2 \mathrm{X} \mathrm{CTAB}$ (cetyltrimethylammonium bromide), and subsequently stored in a freezer at $-20{ }^{\circ} \mathrm{C}$ until DNA extraction.

\section{DNA extraction and PCR}

We employed the efficient method described by Doyle and Doyle (1987) to extract DNA, with some adaptations. We used: $100 \mathrm{mM}$ of Tris $\mathrm{pH} 8.0 ; 1.4 \mathrm{M}$ of $\mathrm{NaCl} ; 20 \mathrm{mM}$ of EDTA pH 8.0; 2\% (p/v) CTAB; 1\% (p/v) PVP-40 and $0.2 \%(\mathrm{v} / \mathrm{v})$ of $\beta$ - mercaptoethanol preheated to $60{ }^{\circ} \mathrm{C}$ in a water bath. The extracted DNA was diluted to TE (Tris-HCl $10 \mathrm{mM}$; EDTA mM pH 8.0) and quantified in an $\mathrm{Epoch}^{\mathrm{TM}}$ and then diluted to $50 \mathrm{ng} . \mathrm{L}^{-1}$.

The polymerase chain reaction (PCR) was performed with the use of six ISSR primers (from the University of British Columbia, UBC primer set \#9, Vancouver, Canada) (Table 2). The PCR mix was composed of buffer (10 X), BSA (1.0 mg.mL $\left.{ }^{-1}\right), \operatorname{MgCl}_{2}(50 \mathrm{mM})$, dNTP $(2.5 \mathrm{mM})$, primer $(2 \mu \mathrm{M})$, Taq polymerase $\left(5.0 \mathrm{U} . \mu \mathrm{L}^{-1}\right)$, DNA and ultrapure water, with a final volume of $12 \mu \mathrm{L}$. The PCRs were performed in a Veriti ${ }^{\mathrm{TM}}$ thermal cycler. The sample amplification program was $94^{\circ} \mathrm{C}$ for 5 minutes, followed by 37 cycles at $94{ }^{\circ} \mathrm{C}$ ( 15 seconds), $47^{\circ} \mathrm{C}$ ( 30 seconds) and $72{ }^{\circ} \mathrm{C}$, for 1 minute. We included a final extension at $72{ }^{\circ} \mathrm{C}$ ( 7 minutes) with cooling at $4{ }^{\circ} \mathrm{C}$. The PCR products were submitted to electrophoresis on $1.5 \%(\mathrm{p} / \mathrm{v})$ agarose gel with TAE buffer (Tris-acetate-EDTA) and stained with GelRed $^{\mathrm{TM}}$. We applied a molecular weight DNA ladder of $1 \mathrm{~kb}$. After electrophoresis, the gels were photographed with ultraviolet light in E-Box ${ }^{\mathrm{TM}} \mathrm{VX} 2$ equipment.

\section{Data analysis \\ Genetic diversity}

We constructed a binary matrix based on the presence (1) and absence (0) of the loci. The parameters of genetic diversity were analysed in the POPGENE 1.32 program (YEH et al., 1997), where the percentage of polymorphic loci $(P)$, number of alleles $(\mathrm{Na})$, effective number of alleles $(\mathrm{Ne})$, Nei's index $(h)$ and Shannon index (I) were obtained for the populations. The diversity indices $h$ and $I$ were submitted to analysis of variance (ANOVA) 
using BioEstat v.5.3 program (AYRES et al., 2007).

\section{PIC value}

The polymorphism information content (PIC) was calculated to measure the efficiency of initiators used in showing the polymorphism between individuals. We used the formula proposed by Anderson et al. (1993) to estimate the PIC: $\mathrm{PIC}_{\mathrm{i}}=1-\sum_{\mathrm{j}-1}^{\mathrm{n}} \mathrm{P}_{\mathrm{ij}}^{2}$ where $\mathrm{P}_{\mathrm{ij}}$ is the frequency of the allele " $\mathrm{j}$ " in the marker " "'". The value obtained at the end of the calculation classifies the primers into three categories, being "satisfactorily informative", when PIC is above 0.50; "moderately informative", when PIC varies between 0.25 and 0.50; and "less informative", when the value of PIC is below 0.25 (BOTSTEIN et al., 1980).

\section{Population genetic structure}

The analysis of molecular variance (AMOVA) between the three populations was obtained employing the ALERQUIM 3.1 program (EXCOFFIER et al., 1992), the AMOVA estimates the population differentiation based on molecular data. A dendrogram was constructed using the NTSYS program (ROHLF, 1993) by the UPGMA grouping method and concerning Nei's genetic identity (1978). Correlation between the genetic distance of Nei and geographical distance was analysed by the Mantel test using the PC-Ord 4.14 program (MCCUNE; MEFFORD, 1997) with 1,000 Monte Carlo permutations.

\section{Bayesian Analysis}

The number of genetic groups $(K)$ was determined through Bayesian analysis using the STRUCTURE v.2.2 program (PRITCHARD et al., 2000). The value of $K$ ranged from 1 to 3, and was obtained employing the admixture ancestry model based on correlated allele frequencies. We used ten independent races for each value of $K$. The races were performed to use the Monte Carlo method with 250,000 random permutations via Monte Carlo Markov Chain (MCMC) and burn-in of 500,000 . The value of $K$ was verified according to the $\Delta K$ method, implemented in the Structure Harvester program (EVANNO et al., 2005; EARL; VONHOLDT, 2012).

\section{Genetic bottleneck}

The significant decreases in the effective population size were obtained in the Bottleneck 1.2.02 program (CORNUET; LUIKART, 1996). The analysis is carried out from allele frequency data and is based on the principle that populations which have undergone a genetic bottleneck present a reduced number of alleles (NEI; ROYCHOUDHURY, 1974). The appropriate mutation model for ISSR markers is the intermediary between the infinite allele model (IAM) (KIMURA; CROW, 1964) and the stepwise mutation model (SMM) (KIMURA; OTHA (1978). Thus, the IAM and SMM models were used for detecting bottlenecks in this work, where the signal test ( $\alpha$ $=0.05$ ) was used from the allele frequencies to point out significant genetic bottlenecks (CORNUET; LUIKART, 1996).

\section{Results and discussion}

\section{Genetic polymorphism and PIC value}

The ISSR primers used generated 79 loci ranging from 10 to 15 and averaging 13 per primer (Table 2). The PIC values ranged from 0.48 to 0.50 , with an average of 0.49 , classifying the primers as moderately informative. The primers with the highest PIC values were the UBC 825 and the UBC 826 , followed by UBC 822 , showing to be efficient in detecting polymorphism between individuals (Table 2).

A large number of loci were obtained from the use of the few primers; a fact that contributed to developing the research when a reduction in the cost and a minimum amount of time were available for this study. Some studies have shown that it is possible to discriminate between genotypes and populations with a reduced number of loci. For example, Hamza et al. (2012) studied the palm tree Phoenix dactylifera $\mathrm{L}$. with the use of six primers and 43 loci. While in researching with the Butia genus (Arecaceae), Gaieiro et al. (2011) selected five primers which generated 74 loci. For the PIC, the average value of 0.49 indicates that the primers used are in the moderately informative range, like that observed by Pinheiro et al. (2017) in studies using ISSR markers with Copernicia prunifera (Mill.) H.E. Moore.

\section{Genetic diversity}

Considering all populations, the number of polymorphic loci was 78 (99\%) (Table 3). The total number of alleles observed was close to 2.00 , and the effective number of alleles was 1.66. Diversity indices had means of $h=0.24$ and $I=0.35$ (Table 3 ). The population with the highest number of polymorphic loci was the MAT, with 57 loci (72\%), followed by RIA with 54 loci $(68 \%)$ and HOR with only 34 loci $(43 \%)$. The number of alleles $(\mathrm{Na})$ and effective number of alleles $(\mathrm{Ne})$ had the same pattern. The MAT and RIA populations showed no statistical difference between their genetic diversity indices $(h$ and $I$ ).

The HOR population had statistically lower genetic diversity than the MAT and RIA populations. The observed variation may have been due to the smallest population size, the usage history of the species in the region and the anthropogenic influences nearby. The most significant genetic similarity between the RIA and MAT populations suggests greater historical gene flow between the two. These populations also have a higher homogeneity of environments in their location. Both have better conservation status according to the anthropogenic pressure scale (Table 1), and have environmental factors in 
their favour such as the slope of the soil and watercourse towards MAT-RIA. Although the slope of the land remains the same for the HOR population, anthropogenic pressure such as roads and civil construction isolate this population from the others, and probably could lead to maintaining genetic differentiation (NATHAN et al., 2017).

\section{Population genetic structure}

The lowest genetic distance observed was among the MAT and RIA populations (0.24), and the most significant genetic distance was among the HOR and MAT populations (0.40) (Table 4). These two populations also have a greater geographical distance from each other (1.45 Km).

AMOVA indicated that there is a higher proportion of genetic variability within populations (58\%) than among populations (42\%) (Table 5). The Mantel test revealed the existence of a positive correlation between genetic and geographic distances between populations, but which was not significant $(r=0.62 ; P>0.05)$. According to Lee et al. (2002), genetic diversity among and within populations is a result of several historical events and recent evolutionary processes. Isolated populations tend to have low gene flow between them, and thus high population differentiation.

The Cluster analysis (Figure 1) shows that the most similar populations are MAT and RIA (0.79), which are closer geographically, and probably makes it possible to share alleles with each other. These two populations are also more similar regarding the anthropogenic pressure scale, both of which are more protected than HOR.

\section{Bayesian analysis}

The Bayesian analysis revealed the existence of three distinct genetic groups $(K=3)$, according to the LnP (D) and $\Delta K$ values. The three groups $(K=3)$ indicated that populations have distinct genotypes (Figure 2). It was possible to verify the geographic distribution patterns of genotypes through the Bayesian analysis, which presented the formation of three groups. Although populations are spatially close to each other, there is high genetic differentiation, probably due to the anthropogenic actions in the region to the cutting of individuals and the isolation of populations.

\section{Genetic bottleneck}

We observed statistical significance in the IAM and SMM models for the HOR population (Table 6). However, a bottleneck for the RIA population was only detected in the IAM model. The MAT population did not demonstrate a genetic bottleneck in either model.

According to the IAM model, despite the RIA population being the most genetically diverse population, it suffered a significant population decrease. The two models were both significant for the HOR population, corroborating the low values of genetic diversity and intense anthropic activity at the site. The construction of roads, the building of houses, and land use for urban and agricultural operations could all be the causes of the occurrence of bottlenecks. Anthropogenic advance leads to a decline in biodiversity and results in fragments of isolated vegetation (NEWBOLD et al., 2015).

The increase in anthropogenic activities is probably one of the main factors responsible for reducing the Elaeis guineensis population, which perhaps diminishes ecological interactions with damage to the maintenance of the evolutionary potential in the long-term. When species are not adapted to climatic and environmental conditions, their survival is more difficult and subject to stochastic events (BARRETT; KOHN, 1991; YOUNG et al., 1996). According to Conceição and Muller (2000), Elaeis guineensis is a monoecious species. Asynchrony in anthesis is common and makes it less likely that selfpollination occurs, and that pollination mechanisms (wind, insects, etc.) are available for gene flow both within and between populations of this plant.

\section{Implications for conservation and breeding}

The data obtained in this study are essential to support breeding and conservation projects of $E$. guineensis in Brazil. It indicates that the determination of priority populations for conservation is essential to support the economic viability of cultivating $E$. guineensis. For example, the RIA population presented large values of diversity and should be prioritised in conservation strategies because it shows significant population decreases. Additionally, the HOR population presented significant bottlenecks in both models and has low diversity indexes, making it a priority for the conservation of the remaining genetic resources. The information in this study may support conservation projects for the species, indicating priority populations and divergent genotypes for implanting germplasm banks.

However, this study was only based on three $E$. guineensis populations in one small area of Brazil. It is still unknown how these populations relate to other populations elsewhere in Brazil, or indeed to the other palm oil producing areas of the world. However, these are all non-native populations of a species which is endemic to West Africa, and it remains unknown how much of the genetic diversity of wild populations has been transported around the world. Although we are advocating that conservation of genetic diversity is important in Brazil, it is also vital that the wild populations are also conserved. It is this genetic resource, which only exists in West Africa, which could be important in the future when genes are required for ensuring resistance to fungal, bacteriological or viral diseases, or to reduce damage by nematodes, mites, insects or other potential pests. This conservation needs to be considered in any country growing oil palms, but is especially vital within the West African range of this economically important species. 
Table 1. Population references, geographic coordinates, sample size $(n)$ and anthropogenic pressure scale of the three Elaeis guineensis populations.

\begin{tabular}{|c|c|c|c|c|c|c|}
\hline Population & Lat. /Long. & $n$ & Vegetation & Soil use & Environment & $\begin{array}{c}\text { Anthropogenic } \\
\text { pressure }\end{array}$ \\
\hline $\begin{array}{c}\text { HOR } \\
\text { (Horta) }\end{array}$ & $5^{\circ} 52^{\prime} 58^{\prime \prime} \mathrm{S} / 35^{\circ} 21^{\prime} 47^{\prime \prime} \mathrm{O}$ & 13 & $\begin{array}{l}\text { Riparian forest } \\
\text { and open } \\
\text { vegetation }\end{array}$ & $\begin{array}{c}\text { Growing } \\
\text { vegetables } \\
\text { and logging }\end{array}$ & $\begin{array}{l}\text { Declivity and high } \\
\text { humidity }\end{array}$ & 4 \\
\hline $\begin{array}{l}\text { MAT } \\
\text { (Mata) }\end{array}$ & $5^{\circ} 53^{\prime} 28^{\prime \prime} \mathrm{S} / 35^{\circ} 21^{\prime} 10^{\prime \prime} \mathrm{O}$ & 15 & $\begin{array}{l}\text { Atlantic forest } \\
\text { fragment edge }\end{array}$ & $\begin{array}{l}\text { Agricultural } \\
\text { use and trails }\end{array}$ & $\begin{array}{l}\text { High humidity and } \\
\text { organic matter content }\end{array}$ & 3 \\
\hline $\begin{array}{c}\text { RIA } \\
\text { (Riacho) }\end{array}$ & $5^{\circ} 53^{\prime} 06^{\prime \prime} \mathrm{S} / 35^{\circ} 21^{\prime} 42^{\prime \prime} \mathrm{O}$ & 15 & $\begin{array}{c}\text { Closed } \\
\text { vegetation and } \\
\text { ciliary forest }\end{array}$ & Roads & $\begin{array}{l}\text { River course, rocks } \\
\text { and declivities }\end{array}$ & 2 \\
\hline
\end{tabular}

Table 2. Summary of ISSR primers used, the nucleotide sequence, number of loci, and PIC value.

\begin{tabular}{cccc}
\hline ISSR primers & Sequence $\left(5^{\prime}-3^{\prime}\right)$ & Loci & PIC \\
\hline UBC 807 (AG)8-T & AGA GAG AGA GAG AGA GT & 15 & 0.49 \\
UBC 822 (TC)8-A & TCT CTC TCT CTC TCT CA & 10 & 0.50 \\
UBC 825 (AC)8-T & ACA CAC ACA CAC ACA CT & 11 & 0.50 \\
UBC 826 (AC)8C & ACA CAC ACA CAC ACA CC & 15 & 0.50 \\
UBC 827 (AC)8G & ACA CAC ACA CAC ACA CG & 14 & 0.48 \\
UBC 857 (AC)8-YG & ACA CAC ACA CAC ACA CYG & 14 & 0.49 \\
\hline Average & & 13 & 0.49 \\
\hline
\end{tabular}

$\mathrm{R}=$ purine $(\mathrm{A}$ ou $\mathrm{G}) \mathrm{e} \mathrm{Y}=$ pyrimidine $(\mathrm{C}$ ou $\mathrm{T})$

Table 3. Measures of genetic diversity in Elaeis guineensis populations.

\begin{tabular}{cccccc}
\hline Populations & polymorphic loci $/ \%$ & $N a$ & $N e$ & $h$ & $I$ \\
\hline HOR & $34 / 43 \%$ & $1.43 \pm 0.01$ & $1.29 \pm 0.06$ & $0.17 \pm 0.04 \mathrm{~b}$ & $0.25 \pm 0.05 \mathrm{~b}$ \\
MAT & $57 / 72 \%$ & $1.72 \pm 0.06$ & $1.45 \pm 0.05$ & $0.27 \pm 0.03 \mathrm{a}$ & $0.40 \pm 0.04 \mathrm{a}$ \\
RIA & $54 / 68 \%$ & $1.68 \pm 0.06$ & $1.45 \pm 0.05$ & $0.28 \pm 0.03 \mathrm{a}$ & $0.41 \pm 0.04 \mathrm{a}$ \\
\hline Average & $48 / 61 \%$ & 1.61 & 1.40 & 0.24 & 0.35 \\
\hline Total & $78 / 99 \%$ & $1.99 \pm 0.01$ & $1.66 \pm 0.03$ & $0.38 \pm 0.02$ & $0.552 \pm 0.02$ \\
\hline
\end{tabular}

Polymorphic loci, percentage of polymorphic loci (\%), number of alleles $(\mathrm{Na})$, effective number of alleles $(\mathrm{Ne})$, Nei's index $(h)$, and Shannon index $(I)$. The values represent the mean \pm standard error. The averages followed by the same letter in the column do not differ significantly from each other by the Tukey Test at $5 \%$ probability.

Table 4. Estimates of the genetic distances of Nei (1978) below the diagonal, and geographic distance (Km) above the diagonal between the Elaeis guineensis populations.

\begin{tabular}{cccc}
\hline Populations & HOR & MAT & RIA \\
\hline HOR & 0 & 1.45 & 0.39 \\
MAT & 0.40 & 0 & 1.06 \\
RIA & 0.25 & 0.24 & 0 \\
\hline
\end{tabular}


Table 5. Analysis of molecular variance (AMOVA) among populations and between individuals within of the Elaeis guineensis populations.

\begin{tabular}{cccccc}
\hline Source of variation & $d f$ & SS & Variance component & Percentage of variation & $P$ \\
\hline Among populations & 2 & 203.784 & 6.51 & $42 \%$ & $<0.00^{*}$ \\
Within populations & 40 & 354.123 & 8.85 & $58 \%$ & \\
\hline Total & 42 & 557.91 & 15.36 & $100 \%$ & \\
\hline
\end{tabular}

Genetic differentiation Fst:

0.42

$d f$ : degrees of freedom; SS: sum of squared deviations; Fst: Genetic differentiation. P: probability.

Table 6. Bottleneck tests between mutation and genetic drift for the Elaeis guineensis populations in the IAM and SMM models.

\begin{tabular}{cccccccc}
\hline \multirow{2}{*}{ Populations } & \multicolumn{4}{c}{ IAM } & & \multicolumn{3}{c}{ SMM } \\
\cline { 2 - 4 } \cline { 6 - 8 } & $n$ & $H e$ & $P$ & & $n$ & $H e$ & $P$ \\
\hline HOR & 34.75 & 27 & $0.05^{*}$ & & 43.50 & 27 & $0.00^{*}$ \\
MAT & 37.26 & 44 & 0.08 & & 44.14 & 42 & 0.35 \\
RIA & 37.43 & 50 & $0.00^{*}$ & & 44.52 & 47 & 0.33 \\
\hline
\end{tabular}

$n=$ expected number of loci with excess heterozygosity under the respective model; $H e=$ number of loci with excess heterozygosity; $P=$ probability; * = significant at 5\% probability; IAM = infinite allele model and SMM = stepwise mutation model.
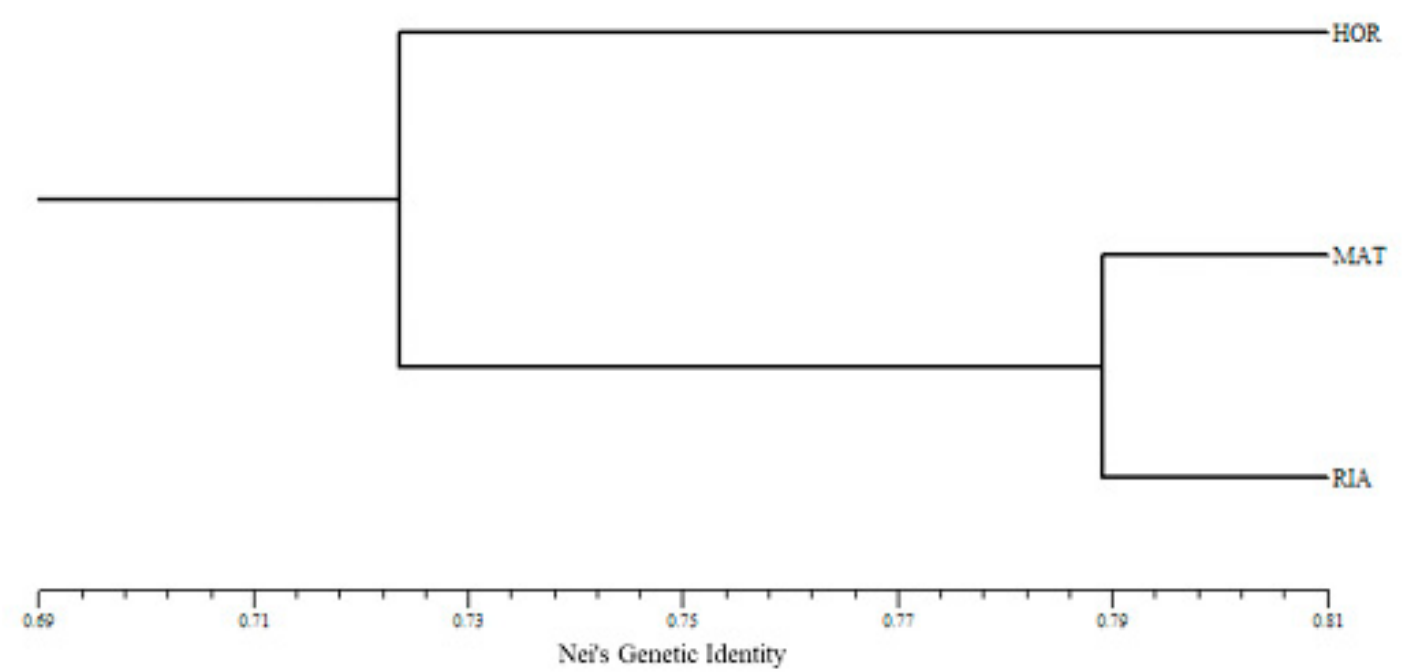

Figure 1. UPGMA dendrogram based on Nei's genetic identity between three Elaeis guineensis populations. 


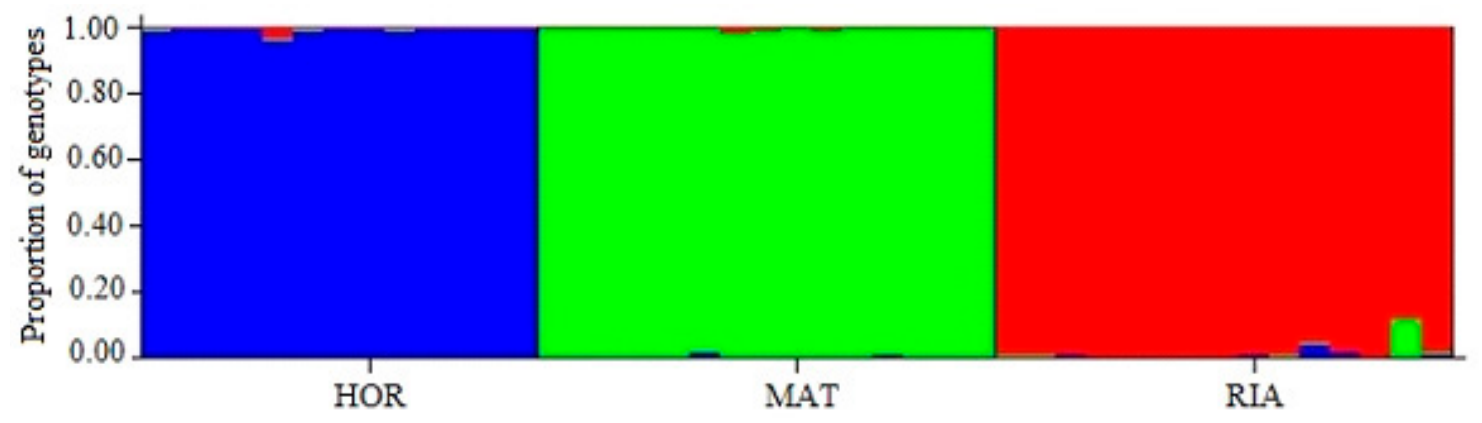

Figure 2. The genotypic proportion between the three Elaeis guineensis populations showing $K=3$. The populations are bounded by the vertical bars. The three different colours indicate the three distinct groups.

\section{Acknowledgements}

We thank the Conselho Nacional de Desenvolvimento Cientifico e Tecnológico $(C N P q)$ for providing scientific initiation scholarship for KPTC. This study was financed in part by the Coordenação de Aperfeiçoamento de Pessoal de Nivel Superior - Brasil (CAPES) - Finance Code 001, as well as a Post-doctoral Scholarship Abroad for FAV, process no. 88881.118979/2016-01. We also thank Professor Michael B. Usher for his suggestions and assistance in editing the English of the manuscript.

\section{References}

ABREU, Y.V.; OLIVEIRA, M.A.G.; GUERRA, S.M. Energia, economia e rotas tecnológicas: textos selecionados. Palmas: Eumed, 2010. 330 p.

ADHIKARI, S.; SAHA, S.; BISWAS, A.; RANA, T.S.; BANDYOPADHYAY, T.K.; GHOSH, P. Application of molecular markers in plant genome analysis: a review. The Nucleus, Havana, v.60, n.3, p.283-297, 2017.

ANDERSON, J.A.; CHURCHILL, G.A.; AUTRIQUE, J.E.; TANKSLEY, S.D.; SORRELLS, M.E. Optimizing parental selection for genetic linkage maps. Genome, Ottawa, v.36, n.1, p.181-186, 1993.

AYRES, M.; AYRES JUNIOR, M., AYRES, D.L.; SANTOS, A.S. Bioestat 5.3 - aplicações estatísticas nas áreas das ciências biomédicas. Belém: ONG Mamiraua, 2007. $364 \mathrm{p}$.

BARRETT, S.C.H.; KOHN, J.R. Genetic and evolutionary consequences of small population size in plants: implications for conservation. In: FALK, D.A.; HOLSINGER, K.E. (ed.). Genetic and conservation of rare plants. New York: Oxford University Press, 1991. p.3-30.
BOTSTEIN, D.; WHITE R. L.; SKOLNICK, M.; DAVIS R.W. Construction of a genetic linkage map in man using restriction fragment length polymorphisms. The American Journal of Human Genetics, Chicago, v.32, p.314-331, 1980.

BRANDÃO, M.M.; VIEIRA, F.A.; CARVALHO, D. Estrutura genética em microescala espacial de Myrcia splendens (Myrtaceae). Revista Árvore, Viçosa, MG, v.35, n.5, p.957-964, 2011.

CHAGAS, K.P.T.; SOUSA, R.F.; FAJARDO, C.G.; VIEIRA, F.A. Seleção de marcadores ISSR e diversidade genética em uma população de Elaeis guineensis. Revista Brasileira de Ciências Agrárias, Recife, v.10, n.1, p.147152, 2015.

CONCEIÇÃO, H.E.O.; MULLER, A.A. Botânica e morfologia do dendezeiro. In: VIÉGAS, I.J.M.; MULLER, A.A. (ed.). A Cultura do dendezeiro na Amazônia brasileira. Belém: Embrapa Amazônia Oriental, 2000. p.31-44.

CORNUET, J.M.; LUIKART, G. Description and power analysis of two tests for detecting recent population bottlenecks from allele frequency data. Genetics, Austin, v.144, p.2001-2014, 1996.

DOYLE, J.J.; DOYLE, J.L.Isolation of plant DNA from fresh tissue. Focus, Rockville, v.12, n.1, p.13-15.1987.

EARL, D.A.; VONHOLDT, B.M. Structure harvester: a website and program for visualizing Structure output and implementing the Evanno method. Conservation Genetics Resources, Netherlands, v.4, n.2, p.359-361, 2012.

EVANNO, G.; REGNAUT, S.; GOUDET, J. Detecting the number of clusters of individuals using the software structure: a simulation study. Molecular Ecology, London, v.14, p.2611-2620, 2005. 
EXCOFFIER, L.; SMOUSE, P.E.; QUATTRO, J.M. Analysis of molecular variance inferred from metric distances among DNA haplotypes: application to human mitochondrial DNA restriction data. Genetics, Austin, v.131, p.479-491, 1992.

FAURBY, S.; EISERHARDT, W.L.; BAKER, W.J.; SVENNING, J.C. An all-evidence species-level supertree for the palms (Arecaceae). Molecular Phylogenetics and Evolution, Orlando, v.100, p.57-69, 2016.

FERREIRA, C.B.B.; LOPES, M.T.G.; CUNHA, R.N.V.; MOREIRA, D.A.; BARROS, W.S.; MARTIELLO, R.R. Diversidade genética molecular de progênies de dendezeiro. Pesquisa Agropecuária Brasileira, Brasília, DF, v.47, n.3, p.378-384, 2012.

GAIEIRO, P.; MAZELlA, C.; A GOSTINi, G.; BERTOLAZZI, S.; ROSSATO, M. Genetic diversity among endangered Uruguayan populations of Butia Becc. species based on ISSR. Plant Systematics and Evolution, Wien, v.292, p.105-116, 2011.

HAMZA, H.; BENABDERRAHIM, M.A.; ELBEKKAY, M.; FERDAOUS, G.; TRIKI, T.; FERCHICHI, M. Investigation of genetic variation in Tunisian date palm (Phoenix dactylifera L.) cultivars using ISSR marker systems and their relation with fruit characteristics. Turkish Journal of Biology, Ankara, v.36, p.449-458, 2012.

KIMURA, M.; CROW, J. The number of alleles that can be maintained in a finite population. Genetics, Austin, v.49, n.4, p.725-738, 1964.

KIMURA, M.; OTHA, T. Stepwise mutation model and distribution of allelic frequencies in a finite populations. Proceedings of the National Academy of Sciences of the USA, Washington, v.75, n.6, p.2868-2872, 1978.

KUSS, V.V.; KUSS, A.V.; ROSA, R.G.; ARANDA, D.A.G.; CRUZ, Y.R. Potential of biodiesel production from palm oil at Brazilian Amazon. Renewable and Sustainable Energy Reviews, New York, v.50, p.10131020, 2015.

LEE, S.L.; NG, K.K.S.; SAW, L.G.; NORWATI, A.; SALWANA, M.H.S.; LEE, C.T.; NORWATI, M. Population genetics of Intsia palembanica (Leguminosae) and genetic conservation of Virgin Jungle Reserves in Peninsular Malaysia. American Journal of Botany, Lancaster, v.89, p.447-459, 2002.
MARTINS, R.C.; FILGUEIRAS, T.S.; ALBUQUERQU, U.P. Ethnobotany of Mauritia flexuosa (Arecaceae) in a Maroon community in Central Brasil. Economic Botany, New York, v.66, n.1, p.91-98, 2012.

MCCUNE, B.; MEFFORD, M.J. Multivariate analysis of ecological data. Version 3.0. Gleneden Beach: MjM Sotware, 1997.

NATHAN, L.R.; KANNO, Y.; VOKOUN, J.C. Population demographics influence genetic responses to fragmentation: A demogenetic assessment of the 'one migrant per generation' rule of thumb. Biological Conservation, Oxford, v.210, p.261-272, 2017.

NEI, M. Estimation of average heterozygosity and genetic distance from a small number of individuals. Genetics, Austin, v.89, p.583-590, 1978.

NEI, M.; ROYCHOUDHURY, A.K. Sampling variances of heterozygosity and genetic distance. Genetics, Austin, v.76, p.379-390, 1974.

NEWBOLD, T.; HUDSON, L.N.; HILL, S.L.L.; CONSTU, S.; LYSENKO, I.; SENIOR, R.A.; et al. Global effects of land use on local terrestrial biodiversity. Nature, London, v.520, p.45-50, 2015.

PINHEIRO, L.G.; CHAGAS, K.P.T.; FREIRE, A.S.M.; FERREIRA, M.C.; FAJARDO, C.G.; VIEIRA, F.A. Anthropization as a determinant factor in the genetic structure of Copernicia prunifera (Arecaceae). Genetics and Molecular Research, Ribeirão Preto, v.16, p.1-14, 2017.

PRITCHARD, J.K.; STEPHENS, M.; DONNELLY, P. Inference of population structure using multilocus genotype data. Genetics, Austin, v.155, p.945-959, 2000.

ROHLF, F. J. NTSYS: numerical taxonomy and multivariate analysis system. New York: Exeter Software, 1993. v.18.

SANTOS, R.M; VIEIRA, F.A. Análise estrutural do componente arbóreo de três áreas de cerrado em diferentes estádios de conservação no município de Três Marias, Minas Gerais, Brasil. Cerne, Lavras, v.11, n.4, p.399408, 2005. 
USDA - United States Department of Agriculture. Economics, statistics, and market information system. Ithaca, Cornell University Library, 2012.

VIEGAS, M.P.; SILVA, C.L.S.P.; MOREIRA, J.P.; CARDIN, L.T.; AZEVEO, V.C.R.; CIAMPI, A.Y.; FREITAS, M.L.M.; MORAIS, M.L.T.; SEBBENN, A.M. Diversidade genética e tamanho efetivo de duas populações de Myracrodruon urundeuva Fr. All., sob conservação ex situ. Revista Árvore, Viçosa, MG, v. 35, n. 4, p. 769-779, 2011.
YEH, F.C.; YANG, R.C.; BOYLE, T.B.J.; YE, Z.H.; MAO, J.X. POPGENE, the user-friendly shareware for population genetic analysis molecular biology and biotechnology center. Edmonton: University of Alberta, 1997.

YOUNG, A.; BOYLE, T.; BROWN, T. The population genetic consequences of habitat fragmentation for plants. Trends in Ecology \& Evolution, Amsterdam, v. 11, n. 10, p. 413-418, 1996. 